\title{
Implementing Social and Emotional Learning Standards by Intertwining the Habits of Mind with the CASEL Competencies
}

Excelsior: Leadership in Teaching and Learning 2019, Vol. 12(1) 3-16

(C) The Author 2019 CC-BY 4.0 International Reprints and permissions: surface.syr.edu/excelsior https://doi.org/10.14305/jn.1 9440413.2018.12.1.03 nyacte.org

\section{Kimberly Alexander ${ }^{1}$ and Paul Vermette ${ }^{2}$}

\begin{abstract}
The New York State Education Department (NYSED) adopted a set of three standards for social and emotional learning (SEL) in August 2018. In doing so, they have paved the way for explicit instruction in and assessment of $21^{\text {st }}$-century skills. The three-goal framework selected by NYSED (2018) is modeled after the five competencies of the Collaborative for Academic, Social, and Emotional Learning (CASEL, 2018). The authors are overjoyed by this movement to promote dual objective learning (Vermette \& Kline, 2017) targeting affective and cognitive goals, but are hesitant to use the CASEL (2018) framework for such SEL standards. Prior to NYSED's (2018) adoption of the new standards, the authors championed the use of Costa and Kallick's 16 Habits of Mind (2000) as the best dispositional framework. Now, however, the authors argue that cross-walking the Habits of Mind (Costa \& Kallick, 2000) to the CASEL (2018) competencies unlocks previously untapped potentials of both frameworks. This article outlines how such an overlap between the frameworks can be achieved, and proposes how the Habits of Mind (Costa \& Kallick, 2000) can be directly used by the students as evidence of their development of the competencies.
\end{abstract}

\section{Keywords}

Social and Emotional Learning, Habits of Mind, CASEL, Dual Objective, Dispositional Framework

In August of 2018, the New York State Education Department (NYSED) took a landmark step in advancing its commitment to educating the whole child by adopting social and emotional learning (SEL) standards and creating useful benchmarks to help clarify assessment expectations. Research has

\footnotetext{
${ }^{1}$ Lewiston-Porter Central School District

2 Niagara University

Corresponding Author:

Kimberly Alexander, Lewiston-Porter Middle School, 4061 Creek Road, Youngstown, NY 14174

Email: kalexander@lew-port.com
} 
shown that in order for students to be successful in the careers of today and tomorrow explicit instruction in $21^{\text {st }}$-century skills, such as critical thinking, grit, and teamwork, must be provided in our schools (Costa \& Kallick, 2014; Duckworth, 2016; Tough, 2016). Jagers, Harris, and Skoog (2015) claimed that SEL competencies could predict achievement measurements like grade point averages and test scores, and in fact many studies have shown that social and emotional learning improves cognitive gains (Durlak, Weissberg, Dymnicki, Taylor, \& Schellinger, 2011; Farrington et al., 2012; Steinberg, 2014). A meta-analysis by Durlak et al. (2011) found an 11-percentile gain in academic performance for students who participated in SEL programs. Additionally, Steinberg (2014) further noted that effective SEL programs have been shown to improve students' self-regulation abilities which in turn led to improved grades. Finally, Farrington et al. (2012) found that culturing positive mindsets increased engagement and persistence, which increased student performance. Because of the cognitive and affective gains associated with SEL programs, Author 1, a middle school science teacher, and Author 2, a professor of education, both believe that every lesson should be taught with a dual objective including an affective and cognitive goal (Vermette \& Kline, 2017). In their work, Dispositions, Costa and Kallick (2014) argue that of greater importance than the set of SEL standards chosen is the method of implementation and assessment. For their part, NYSED has selected the Collaborative for Academic, Social, and Emotional Learning (CASEL) framework of five competencies (2018). NYSED (2018) has combined the five competencies into the following three goals.

1. Develop self-awareness and self-management skills essential to success in school and life.

2. Use social awareness and interpersonal skills to establish and maintain positive relationships.

3. Demonstrate ethical decision-making skills and responsible behaviors in personal, school, and community contexts.

These are quite clearly derived from CASEL's (2018) five competencies of (1) self-awareness, (2) self-management, (3) social awareness, (4) relationship skills, and (5) responsible decision-making. While the authors agree with Costa and Kallick's (2014) premise that any SEL model is better than a lack thereof, the authors further argue that Costa and Kallick's 16 Habits of Mind (2000) is a superior set of dispositions particularly as applied to the middle level classroom. Teachers need not sacrifice one model for another, however, as the Habits of Mind (Costa \& Kallick, 2000) intertwine beautifully with the five competencies of CASEL (2018). The authors see the Habits of Mind (Costa \& Kallick, 2000) as the language used with and by the students, as evidence of the CASEL (2018) competencies. In this article, the authors describe how the 16 Habits of Mind (Costa \& Kallick, 2000) can be mapped to the five competencies, simplifying identification and classroom implementation, and the authors propose a method of assessment for this model.

CASEL (2018) color codes its five competencies to suggest a relationship between them. The first and second are coded together as pertaining to self (self-awareness and self-management), while the third and fourth relate to others (social awareness and relationship skills), and the fifth derives from the first four (responsible decision-making). In keeping with this model, the authors view the competencies as a flow chart with the Habits of Mind (Costa \& Kallick, 2000) as supporting features (Figure 1). For each competency, the authors have identified a key habit of mind (bolded text) and at least one supporting habit of mind (Figure 1 ). 


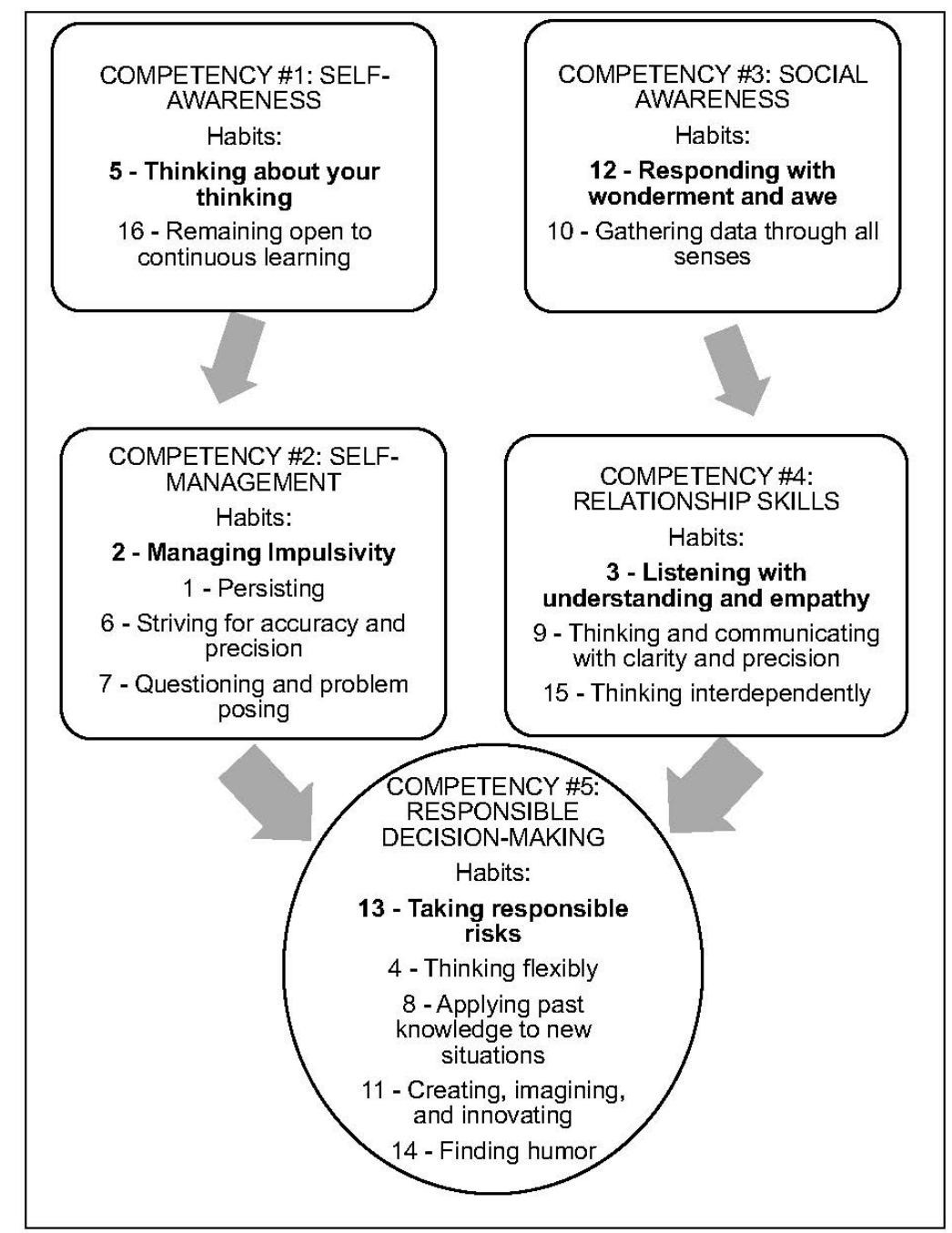

Figure 1. Mapping the 16 Habits of Mind (Costa \& Kallick, 2000) to the five competencies of CASEL (2018). Each competency has a key habit of mind (bolded text) and at least one supporting habit of mind.

CASEL (2018) defines its first competency, self-awareness, as "the ability to accurately recognize one's own emotions, thoughts, and values and how they influence behavior" (CASEL, 2018). Underneath this competency, the supporting criteria listed by CASEL include "identifying emotions, accurate self-perception, recognizing strengths, self-confidence, and self-efficacy" (CASEL, 2018). Based on this interpretation of self-awareness, the authors are confident that the fifth habit of mind, metacognition, belongs under this competency and as such identify this as the key habit relating to the first competency. Students cannot recognize their own thoughts if they are not thinking about their thinking. The authors also have placed the sixteenth habit, remaining open to continuous learning, as a supporting habit under self-awareness as this habit suggests learning as a value, and one must be aware of one's own value system.

The second competency of self-management is defined by CASEL (2018) as "the ability to successfully regulate one's emotions, thoughts, and behaviors in different situations - effectively managing stress, controlling impulses, and motivating oneself." The sub-components of this competency 
are listed as "impulse control, stress management, self-discipline, self-motivation, goal-setting, and organizational skills." Naturally, the second habit of mind belongs in this group as its name is in the definition (managing impulsivity). Because of this overlap, the authors see the second habit of mind as the essential key habit for this competency. If one thinks of the second competency as an extension of the first, where the first is recognizing one's thoughts and emotions and the second is regulating and acting on these, then one finds that the first habit of mind, persisting, is a supporting habit in this group. Persistence can happen when one recognizes one's own frustration and then acts on this by continuing with the frustrating task. It can also happen when one returns to a task showing prolonged commitment. Furthermore, the sixth habit of mind, striving for accuracy, also belongs here, because striving to do one's best is an action that results from knowing one's own strengths. Finally, the authors place the seventh habit of mind, questioning and problem posing in this group, because the authors see this as the action that results from recognizing one's confusion and/or uncertainty and that could feed the motivating disposition of student curiosity (Leslie, 2014).

The third competency of social awareness is defined as "the ability to take the perspective of and empathize with others, including those from diverse backgrounds and cultures. The ability to understand social and ethical norms for behavior and to recognize family, school, and community resources and supports" (CASEL, 2018). The corresponding sub-competencies are "perspectivetaking, empathy, appreciating diversity, and respect for others" (CASEL, 2018). Again, the authors view the third and fourth competencies as being intricately connected where the third describes recognition of social situations and the fourth addresses the appropriate actions in these situations. Based on this, the authors have placed the tenth habit of mind, gather data through all senses, under the third competency. Gathering data through the senses requires awareness of one's situation including the physical environment and social and emotional cues. The authors also placed the twelfth habit of mind, responding with wonderment and awe, into this group because this is a positive way of interpreting new and diverse situations and experiences. The authors have chosen to identify the twelfth habit as the key habit of mind for the third competency as it is a more critical component to an SEL program. While gathering data is a common task in many classrooms, this highly cognitive process may not transition into social awareness without using the positive lens of interpretation called for when one responds with wonderment and awe.

Relationship skills, the fourth competency, are defined as "the ability to establish and maintain healthy and rewarding relationships with diverse individuals and groups. The ability to communicate clearly, listen well, cooperate with others, resist inappropriate social pressure, negotiate conflict constructively, and seek and offer help when needed" (CASEL, 2018). The underlying subcompetencies are "communication, social engagement, relationship-building, and teamwork" (CASEL, 2018). At first glance, it may have seemed that the third habit of mind, listening with understanding and empathy belonged under social awareness, but the authors advocate for its placement as the key habit of mind in this fourth group because listening and empathizing are both verbs that imply action to be taken in a social situation. Furthermore, the authors place the ninth habit of mind, thinking and communicating with clarity and precision, in this group as a support. Communication is part of the list of subcompetencies and naturally results from active listening. Finally, the authors find that the fifteenth habit of mind, thinking interdependently, belongs in this group because this implies using teamwork skills to build effective, healthy relationships in diverse groups.

Finally, the fifth competency of responsible decision-making is defined as "the ability to make constructive choices about personal behavior and social interactions based on ethical standards, safety concerns, and social norms" (CASEL, 2018. The sub-competencies are "identifying problems, 
analyzing situations, solving problems, evaluating, reflecting, and ethical responsibility" (CASEL, 2018). Unquestionably, the authors have placed the thirteenth habit of mind, taking responsible risks, as the key habit here as this requires skilled decision-making. The authors see the fifth competency as deriving from the first four. Therefore, once an individual can recognize their own thoughts and emotions, as well as social cues, and knows how to act on these recognitions, the individual must then make responsible decisions. As such, the authors place the fourth habit of mind, thinking flexibly into this group. In order to make wise decisions, one must be able to analyze problems from multiple angles and perspectives. The authors also suggest that the eighth habit of mind, applying past knowledge to new situations, applies here as one can use one's own background knowledge when approaching a new situation. The authors find that creating, imagining, and innovating, the eleventh habit, belongs here as such actions need to be responsibly enacted. Finally, the authors have placed the fourteenth habit of mind, finding humor, into this group as well because one must responsibly find humor so as not to offend others or put oneself down.

\section{Selection of Two Critical Habits of Mind}

The authors would like to briefly mention that they find two Habits of Mind (Costa \& Kallick, 2000) to be most imperative in an SEL framework, especially in the middle school classroom. The authors argue that the second and third habits, managing impulsivity and listening with understanding and empathy, respectively, are the two most important Habits of Mind (Costa \& Kallick, 2000). While they acknowledge all 16 Habits of Mind (Costa \& Kallick, 2000) are critical and should be explicitly taught to students, the authors have found a deep connection between the second and third habits that they suggest serves as the cornerstone for all dispositional learning. The authors see listening as a component of managing impulsivity. Fully managing one's impulses requires being able to do so automatically without much thought. Therefore, a student who is improving on this habit may be able to hold his/her tongue while another is speaking, but may find that he/she needs to devote so much mental energy toward impulse management that he/she reaches cognitive overload without actually listening to the other speaker while waiting his/her turn. By contrast, a student excelling in the second habit can easily refrain from speaking while another is talking because he/she is so actively listening that he/she is not thinking about his/her own response. Because of this overlap, the authors see these two habits as mutually reinforcing and as developing simultaneously. The authors suggest that these habits should be promoted and developed first as they open the doors to learning the other 14 . Without being able to truly listen actively (thereby managing impulses in the process), how can one succeed in learning other skills or content? Furthermore, listening and empathizing are foundational requirements for successful interactions in groups. As most Habits of Mind (Costa \& Kallick, 2000) can and should be developed through well-structured cooperative learning group experiences (Vermette \& Kline, 2017), students must be taught how to listen and empathize before they can be expected to work interdependently toward all other affective goals.

\section{Benefits of Using the Proposed Crosswalk of SEL Frameworks}

The first benefit of using the Habits of Mind (Costa \& Kallick, 2000) is that the language of this framework is more accessible to students than that of the CASEL (2018) competencies and its repackaging as the NYSED (2018) three goals. Brackett (2018) has stressed the importance of 
nuanced vocabulary as part of the RULER method for teaching emotional regulation skills. Brackett, Rivers, Reyes, and Salovey (2012) furthermore noted that explicit instruction in SEL is necessary for students to become proficient in these skills. Therefore, in order for students to metacognitively recognize and identify their use of social and emotional skills, the vocabulary of the SEL program needs to be accessible to the students. The CASEL (2018) competencies and NYSED (2018) goals do not have easily accessible language for students, especially those at the middle level. For example, when one looks at the second goal "use social awareness and interpersonal skills to establish and maintain positive relationships," it is difficult to simply describe what this looks like, sounds like, or feels like. Instead, middle level students can easily break down ideas such as "listening," "understanding," and "communicating," which is the language of some of the corresponding Habits of Mind (Costa \& Kallick, 2000). In Author 1's seventh-grade science classroom, the 16 Habits of Mind (Costa \& Kallick, 2000) are displayed with corresponding "I can" statements (Zachek, n.d.). These "I can" statements make the habit clear to students and provide examples of how students can exemplify the habit. For example, beneath Managing Impulsivity, students find the phrase "I can take my time." This helps cue students to practice the disposition and to reflect on their use of the dispositions in their writing. Because of this, in Figure 2, the authors have redefined their conceptual map to show the five competencies with their own "I can" statements representing the corresponding Habits of Mind (Costa \& Kallick, 2000). As it was in Figure 1, the key habit of mind for each competency is bolded. Please note that the authors suggested that the $16^{\text {th }}$ habit of mind, remaining open to continuous learning, belongs under the first competency as it implies learning is a value and one's values are part of one's social awareness. However, the authors wish to emphasize that the Habits of Mind (Costa \& Kallick, 2000) are cognitive tendencies and not just student beliefs. As such, the authors have carefully constructed the "I can" statement for this habit (Figure 2) to reflect the integration of the growth mindset (Dweck, 2008) into one's understanding of one's own learning. The authors propose that students who understand the physiological changes learning has on their brains are more likely to be open to learning diverse concepts throughout their lifetimes.

A second benefit of using the Habits of Mind (Costa \& Kallick, 2000) mapped to CASEL (2018) is in the development of assessments by teachers and students. A teacher's assessment of a student's SEL should align with the SEL framework explicitly taught. Again, the authors echo the sentiment of Duckworth and Yeager (2015) and acknowledge that individual teachers are certainly capable of determining the dispositional framework that best meets the needs of their students. Teachers must then build assessments in alignment with the dispositions of their choice. Using the student-friendly language of the Habits of Mind (Costa \& Kallick, 2000) makes the assessment language familiar, accessible, and understandable. Schwartz, Tsang, and Blair (2016) noted the importance of feedback in all forms of learning. They also note that feedback must be specific, timely, understandable, non-threatening, and revisable. They point out that feedback shows learners the discrepancy between their idea, action, or behavior and the desired one (Schwartz, Tsang, and Blair, 2016). Just as teachers use feedback to help students grow cognitively, teachers must provide feedback to students to help them grow socially and emotionally. Such feedback can only be given if teachers take the time to assess students' progress according to a social and emotional framework. To start with the three goals (NYSED, 2018) is to give students a broad challenge with an obscure path for achieving success (and no clear method of assessing). 


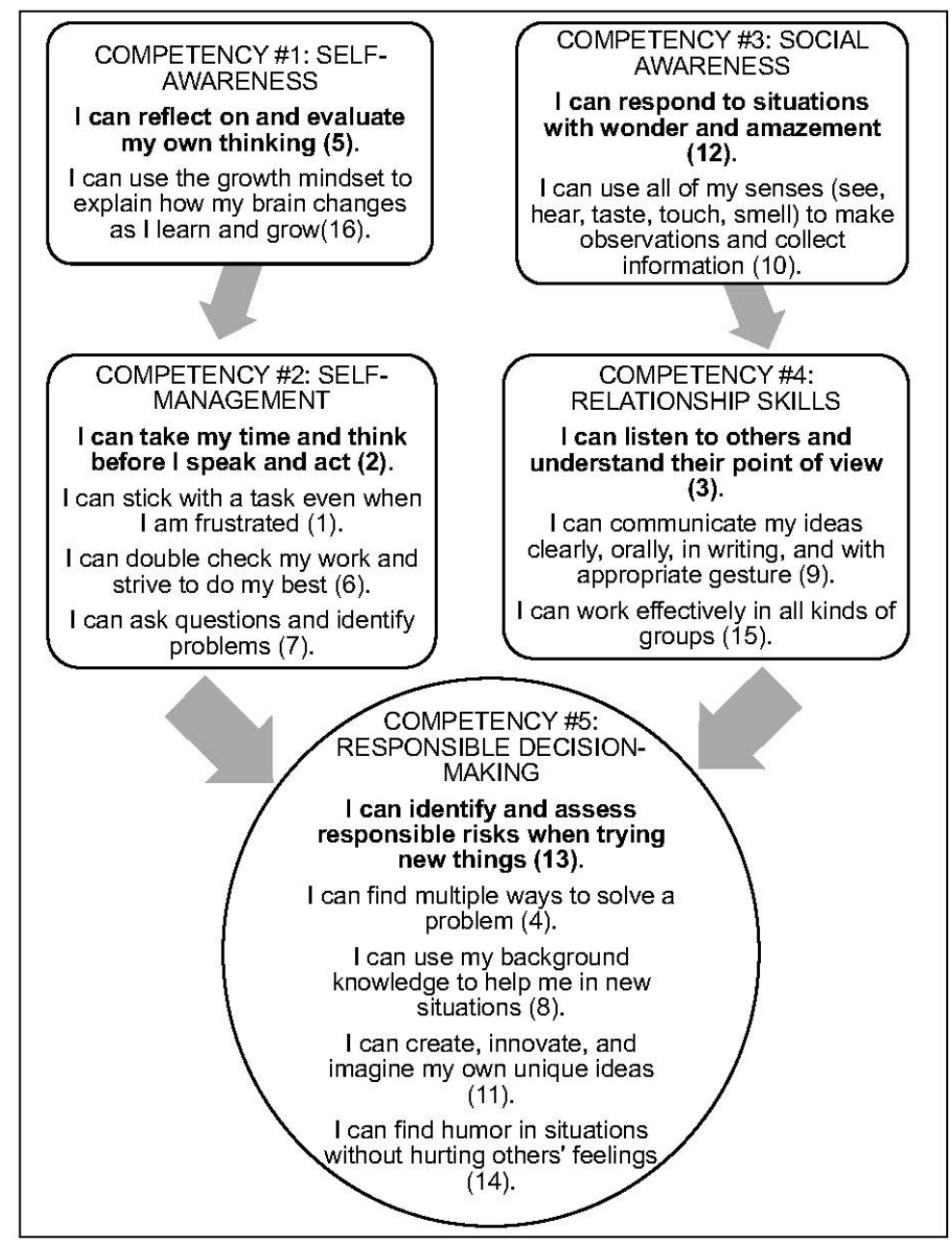

Figure 2. Using "I can" statements to represent the Habits of Mind (Costa \& Kallick, 2000) that correspond to each CASEL (2018) competency. The key habit of mind in each competency is shown in bolded text.

Similarly, using the five CASEL (2018) competencies with 25 sub-competencies is an unworkable number of criteria for assessment. Instead, starting with the Habits of Mind (Costa \& Kallick, 2000) provides students with a road map to building affective skills. The authors argue for the creation of a rubric aligned to each habit, like those shown in Figures 3 and 4 for the second and third habits. The authors have developed these rubrics in conjunction with the "I can" statements they've chosen to support their SEL model. Of course, teachers could and should adapt these rubrics to meet the needs of their students. Duckworth and Yeager (2015) suggest that this autonomy for the individual classroom teacher is imperative as a top-down approach from the state or other higher department would not be tailored to the specific students in each unique classroom. The authors would like to note, however, they have carefully titled the last column "not yet demonstrating" in an effort to promote a growth mindset (Dweck, 2008). Assessments such as the rubrics in Figures 3 and 4 give students a clear outline of what skills are being assessed. This allows students to visualize the habits as separate skills, which therefore chunks the state SEL goals into manageable tasks. For example, if a student is working on managing impulsivity and is shown the rubric in Figure 3 (either to self-assess, or to be assessed on by a teacher), the student can easily recognize the three component skills of the habit that he/she is expected to 
display. Students could even be asked to build their own rubrics, effectively setting their own goals, for each habit.

\begin{tabular}{|c|c|c|c|}
\hline \multicolumn{4}{|c|}{ Habit \#2: Managing Impulsivity } \\
\hline Target & 3 - Excelling & $\begin{array}{l}2 \text { - Valuable but } \\
\text { limited }\end{array}$ & $\begin{array}{l}1 \text { - Not yet } \\
\text { demonstrating }\end{array}$ \\
\hline $\begin{array}{l}\text { I can take my time on } \\
\text { my work. }\end{array}$ & $\begin{array}{l}\text { I deliberately take my } \\
\text { time on my work and I } \\
\text { do not rush. }\end{array}$ & $\begin{array}{l}\text { I try not to rush, but } \\
\text { sometimes I become } \\
\text { impatient with my } \\
\text { work. }\end{array}$ & $\begin{array}{l}\text { I know that I should } \\
\text { take my time but this is } \\
\text { very difficult and I } \\
\text { often rush. }\end{array}$ \\
\hline $\begin{array}{l}\text { I can think before I } \\
\text { speak. }\end{array}$ & $\begin{array}{l}\text { I almost always think } \\
\text { about what I want to } \\
\text { say and how it will } \\
\text { affect others before I } \\
\text { say it. }\end{array}$ & $\begin{array}{l}\text { I try to think before I } \\
\text { speak, but sometimes, } \\
\text { when I am excited or } \\
\text { frustrated, I forget to } \\
\text { do this. }\end{array}$ & $\begin{array}{l}\text { It is difficult for me to } \\
\text { think before speaking. I } \\
\text { usually say the first } \\
\text { thing that comes to } \\
\text { mind as soon as I think } \\
\text { of it. }\end{array}$ \\
\hline $\begin{array}{l}\text { I can wait my turn } \\
\text { and listen to others } \\
\text { without interrupting. }\end{array}$ & $\begin{array}{l}\text { In a conversation, I am } \\
\text { an active listener as } \\
\text { well as participant, } \\
\text { meaning that not only } \\
\text { do I wait to speak and } \\
\text { refrain from } \\
\text { interrupting but I also } \\
\text { engage as a listener. }\end{array}$ & $\begin{array}{l}\text { I try to wait before } \\
\text { speaking but } \\
\text { sometimes while I am } \\
\text { waiting, I forget to } \\
\text { listen. Sometimes, I } \\
\text { also interrupt. }\end{array}$ & $\begin{array}{l}\text { I often interrupt others } \\
\text { and I have a difficult } \\
\text { time listening while } \\
\text { waiting for my turn to } \\
\text { speak. }\end{array}$ \\
\hline \multicolumn{4}{|c|}{ 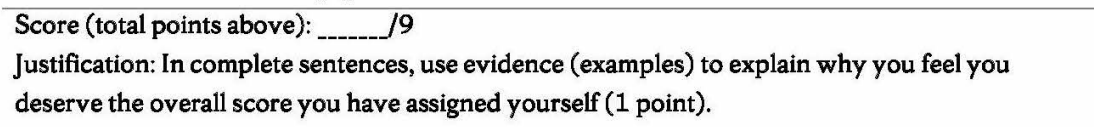 } \\
\hline & & & Total Score \\
\hline
\end{tabular}

Figure 3. Example rubric students can use to self-assess their proficiency with Habit of Mind \#2, Managing Impulsivity from the 16 Habits of Mind (Costa \& Kallick, 2000).

The third and final benefit of mapping the Habits of Mind (Costa \& Kallick, 2000) to CASEL (2018) is in the teacher's and student's ability to monitor progress and development of these social and emotional skills. Naturally, this follows from the use of the assessments described above. Once feedback is provided from the assessments, students should be expected to use this feedback to improve. The teacher (and students) can then use evidence from the Habits of Mind (Costa \& Kallick, 2000) assessments to track a student's progress on the three NYSED (2018) goals. When the language and the goals are accessible to students, the students can then be empowered to monitor their own progress. They can set their own goals and measure their own success. Setting one's own goals increases one's motivation to complete a task as the choice of goal offers student's an aspect of control (National Academies of Sciences, Engineering, and Medicine, 2018). This aligns perfectly with self-determination theory because choice, or autonomy, has been shown to increase motivation (Ryan \& Deci, 2000). The National Academies of Sciences, Engineering, and Medicine (2018) also reported that learners are 
more likely to persist and take on challenges if they feel a sense of control in the learning environment. Students can be asked to choose a habit of mind that they struggle with and would like to improve on. They can then develop a plan for achieving this goal. For example, "I will improve on listening with understanding and empathy by listening to my teammates' ideas and not insisting that I get my own way." The authors note that improving students' self-efficacy has been shown to increase their motivation to achieve such goals (Pajares, 1996). Research has also shown that people are more likely to achieve their goals if they develop a plan for reaching them. Steinberg (2014) noted that students who were encouraged to use a program called Mental Contrasting with Implementation Intentions (MCII) had greater improvement in their grades, attendance, and school conduct. The MCII program teaches students how to set their own goals and make a plan for achieving these goals that considers potential obstacles ahead of time. The authors argue that this MCII approach could also be used to help students set and achieve their own social and emotional goals and that this would be most effective using the language of the Habits of Mind (Costa \& Kallick, 2000) as opposed to the CASEL (2018) competencies.

\begin{tabular}{|c|c|c|c|}
\hline Habit \# 3: Listening wit & Understanding and Em & athy & \\
\hline Target & 3 - Excelling & $\begin{array}{l}\text { 2-Valuable but } \\
\text { limited }\end{array}$ & $\begin{array}{l}1 \text { - Not yet } \\
\text { demonstrating }\end{array}$ \\
\hline $\begin{array}{l}\text { I can actively listen to } \\
\text { others' ideas. }\end{array}$ & $\begin{array}{l}\text { I actively listen to } \\
\text { others. While others } \\
\text { are speaking, I am not } \\
\text { thinking of what I will } \\
\text { say. I can ask questions } \\
\text { to others to show that I } \\
\text { am listening and trying } \\
\text { to understand. }\end{array}$ & $\begin{array}{l}\text { I can listen to others } \\
\text { but I don't always do } \\
\text { so actively. Sometimes } \\
\text { I do not understand } \\
\text { others and I do not ask } \\
\text { for clarification. }\end{array}$ & $\begin{array}{l}\text { I have a hard time } \\
\text { listening to others. I am } \\
\text { more focused on } \\
\text { speaking than listening } \\
\text { in group discussions. }\end{array}$ \\
\hline $\begin{array}{l}\text { I can paraphrase } \\
\text { another person's } \\
\text { point of view and } \\
\text { respectfully agree or } \\
\text { disagree with ideas } \\
\text { different from my } \\
\text { own. }\end{array}$ & $\begin{array}{l}\text { I can summarize what I } \\
\text { heard another person } \\
\text { say and can } \\
\text { understand ideas that } \\
\text { are different from my } \\
\text { own. I can respectfully } \\
\text { agree or disagree with } \\
\text { others after hearing } \\
\text { their side. }\end{array}$ & $\begin{array}{l}\text { I listen to others' ideas } \\
\text { but have a hard time } \\
\text { accepting ideas other } \\
\text { than my own } \\
\text { sometimes. Sometimes, } \\
\text { I confuse summarizing } \\
\text { what I've heard with } \\
\text { judging/evaluating } \\
\text { what I've heard. }\end{array}$ & $\begin{array}{l}\text { I struggle to see how } \\
\text { people think } \\
\text { differently from me } \\
\text { and I need to work on } \\
\text { asking people to } \\
\text { explain ideas that I } \\
\text { don't understand so } \\
\text { that I can better } \\
\text { summarize their ideas } \\
\text { and respectfully agree } \\
\text { or disagree. }\end{array}$ \\
\hline $\begin{array}{l}\text { I can use evidence } \\
\text { and reasoning to } \\
\text { understand how } \\
\text { someone is feeling. }\end{array}$ & $\begin{array}{l}\text { I can empathize with } \\
\text { someone by listening } \\
\text { to how they are feeling } \\
\text { and by trying to share } \\
\text { that emotion. }\end{array}$ & $\begin{array}{l}\text { I can recognize how } \\
\text { someone else is feeling } \\
\text { but I don't know how } \\
\text { to share the emotion } \\
\text { with them. }\end{array}$ & $\begin{array}{l}\text { It is difficult for me to } \\
\text { understand how other } \\
\text { people are feeling and I } \\
\text { do not always ask } \\
\text { others to explain their } \\
\text { emotions. }\end{array}$ \\
\hline \multicolumn{4}{|c|}{ 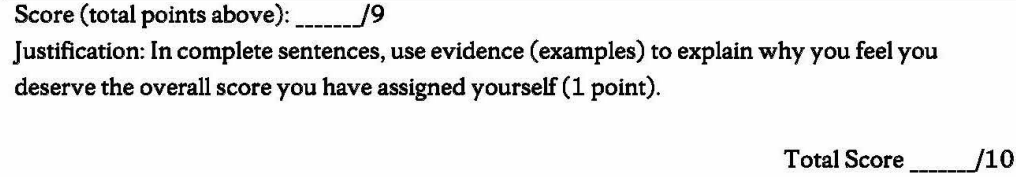 } \\
\hline
\end{tabular}

Figure 4. Example rubric students can use to self-assess their proficiency with Habit of Mind \#3, Listening with Understanding and Empathy from the 16 Habits of Mind (Costa \& Kallick, 2000). 
Because the Habits of Mind (Costa \& Kallick, 2000) chunk social and emotional learning into specific tasks and specific goals, teachers can identify specific strengths and weaknesses for each student. By grouping the Habits of Mind (Costa \& Kallick, 2000) into the CASEL (2018) competencies, teachers can encourage students to practice a diverse array of affective skills by challenging students to work on habits from different competencies. While these groupings could be shown to students like the models in Figures 1 or 2, the authors do not feel this is necessary as the additional layer may add confusion. Furthermore, students will not necessarily benefit from seeing the habits in such groups. The authors suggest that keeping the habits separate for the students encourages them to strive to achieve each one. Author 1 and her collaborative teaching partner are in the process of developing a badge system for the Habits of Mind (Costa \& Kallick, 2000) that will allow students to visualize their SEL development through a form of gamification. Students will earn badges for completing components of each habit in order to eventually earn a badge for the habit as a whole. For example, to earn the "persistence" badge, students first need to earn badges for "overcoming a difficult task", "setting and sticking with a goal" and "staying focused". Badges could then be linked to the CASEL (2018) competencies or NYSED (2018) three goals without using their language in the classroom. Therefore, achieving badges for Habits 5 and 16 could unlock the badge or level for "selfawareness." Students could see this larger level simply as an overarching title without needing explicit instruction in this additional dispositional framework. One point of consideration that Author 1 and her partner are also developing is the importance of students seeing the Habits of Mind (Costa \& Kallick, 2000) as a continual process. They do not want students to view a badge as something they achieve once and then never use again. They feel that having multiple pieces to unlock before earning a habit will help (these are the "I can" statements). Additionally, they plan to reset the badge system at various points, perhaps each marking period, so that students are challenged to re-achieve previous badges.

Implementing the Habits of Mind (Costa \& Kallick, 2000) via the crosswalk with the CASEL (2018) competencies described above can easily be done by the classroom teacher. Author 1 plans to implement this crosswalk in a specific format, but in keeping with Duckworth and Yeager (2015) the authors recognize that no one-size fits all implementation plan will work for all teachers, and each teacher should carefully select his/her set of dispositions and implementation framework. Author 1 is currently developing and field-testing rubrics like those in Figures 3 and 4 for each of the sixteen Habits of Mind (Costa \& Kallick, 2000). In the beginning of the school year, she will use these as exit slips, but will require all students to complete the same rubric on any given day. In this way she can systematically introduce students to all sixteen habits and rubrics. In the middle of the year, she will begin introducing choice of rubrics. Consistent with Glasser (1999), Author 1 finds that offering students' choice in which Habit of Mind (Cota \& Kallick, 2000) they'd like to work on increases motivation. She commonly introduces this during modeling activities, challenging struggling students to work on persisting while encouraging excelling students to work on managing impulsivity. As the year progresses, Author 1 will increase the number of choices of rubrics available to students. By June, as students embark on a final project-based learning unit, students will set their own goals and complete any of the sixteen rubrics as a component of their projects. Some readers may find this implementation plan parallels Fisher and Frey's (2013) gradual release model, but the authors prefer to echo Hattie (2012) by noting the importance of releasing control and opening greater choice to students as the year progresses. Additionally, please note that unlike the gradual release model and behaviorist practices (Fisher and Frey, 2013), students will start using these rubrics on their own after having completed a common experience (the corresponding science lesson) and as such this process starts with the students actively doing something, rather than with the teacher modeling something. 


\section{Conclusion}

The authors are elated at the New York State Education Department's decision to adopt social and emotional learning standards. The authors recognize the growing research base that shows explicit instruction in affective skills results in cognitive gains for students (Durlak et al., 2011; Farrington et al., 2012; Jagers, Harris, \& Skoog, 2015; Steinberg, 2014). In fact, students are seeking more social and emotional learning experiences and acknowledge that they feel these programs help them to do better academically (DePaoli, Atwell, Bridgeland, \& Shriver, 2018). Although the authors appreciate NYSED's (2018) adoption of SEL standards, the authors are concerned that their adaptation of the CASEL (2018) five competencies into the NYSED (2018) three goals represents an inaccessible framework for students with difficult language and generalized ideas. In their 2017 book, Vermette and Kline offer a series of plausible taxonomies for use in guiding the creation of learning targets on the affective side. There are many that fall under the pejorative term "soft skills" and they overlap and complement each other. As already mentioned, CASEL (2018)'s five competencies became the set of choice by NYSED in August 2018, but others, such as "the seven Habits of highly effective people" (Covey, 1989), the "formative five" (Hoerr, 2016), and the so-called "big five" personality traits (that have been adopted by ACT [2019] as they prepare a standardized paper and pencil measure), have their supporters. Given the variety and conceptual flexibility of these alternatives, the authors settled on the Habits of Mind (Costa \& Kallick, 2000). Alhamlan, Aljasser, Amansour, and Alahmad (2018) showed great respect for this framework in their literature review and promoted a systematized use of the Habits of Mind (Costa \& Kallick, 2000) in conjunction with cognitive learning. The authors support the use of the Habits of Mind (Costa \& Kallick, 2000) because they find that the habits represent accessible language, particularly for middle level students, and such language allows for students to be self-directed learners of their own affective skills. The authors also suggest that this student-friendly language allows for clearer teacher and student-developed assessments. Fortunately, the authors find that mapping the Habits of Mind (Costa \& Kallick, 2000) to the CASEL (2018) competencies unlocks previously untapped potential of each framework and provides the best model for implementation and assessment of SEL standards. By interweaving the two models, the authors suggest that teachers can better progress monitor their students by helping them to set clear goals.

The crosswalk of frameworks that the authors propose here has vast implications for teachers, teacher education programs, researchers and students. For teachers, the authors find that their model represents a "ready-to-implement" program of social and emotional learning. Steinberg (2014) found that effective SEL programs are sequenced, active, focused, and explicit. Using this model that crosswalks the Habits of Mind (Costa \& Kallick, 2000) with CASEL (2018)'s five competencies suggests a sequence of skill-building, while providing flexibility in order as well. While the authors argued the importance of beginning with the second and third habits, the authors acknowledge that each student has his/her unique social and emotional learning needs. The authors propose that their model is active, as the student-friendly language empowers students to take an active role in their own SEL assessment and management. This model is focused as it reduces CASEL (2018)'s five competencies with 25 sub-competencies to the more workable number of 16 skills. Finally, the authors agree with Steinberg (2014) and Brackett et al. (2012) and suggest explicit instruction of social and emotional learning. The authors envision teachers and students discussing social and emotional learning through the use of this model during content lessons in the format of the dual objective promoted by Vermette and Kline (2017). Therefore, the authors see their crosswalk as fitting the requirements of an effective 
SEL program as defined by Steinberg (2014) and as such see the model as having great implications for teachers looking to incorporate NYSED's (2018) new SEL standards into their classrooms.

The authors also find that this model has great implications for teacher education programs. Since NYSED's (2018) adoption of SEL standards in August of 2018, one should assume that teacher education programs will look to prepare their students to teach these standards just as they have been preparing teacher candidates to teach content standards. However, the authors acknowledge that encouraging social and emotional learning is becoming more difficult. Borba (2018) describes an empathy crisis in which American teens are $40 \%$ less empathetic than they were thirty years ago, noting that today's students are more competitive, individualistic, and stressed than those of the past. It would seem that solutions to this problem must begin in our teacher education programs so that teacher candidates are equipped to meet the needs of current students. The authors champion the teaching of the dual objective model to teacher candidates (Vermette \& Kline, 2017) and view their model proposed here as a natural extension of its implementation.

Finally, the authors see this model as having implications for researchers. Author 1 has employed this crosswalk in her own middle school classroom and has been conducting action research on it. From this, she has noticed the importance of language accessibility. While Author 1 finds that throughout the school year students can master the language of all sixteen habits, she notes that early in the year students shy away from discussing habits that they don't quite understand. At the start of the year, given the choice to describe a habit of mind that they succeeded with on a project, her seventh-grade science students are much more likely to write about persistence, or striving for accuracy, than they are to choose thinking about your thinking (metacognition) or managing impulsivity. She finds that students don't come with a concept of metacognition or impulsivity, but that the use of clear "I can" statements (Zachek, n.d.) and explicit instruction (as promoted by Steinberg, 2014 and Brackett et al., 2012) enables students to conceptualize these habits in her class. Of course, the authors would love to see more research be done on the model proposed as they understand the limitations of action research.

The authors could not agree more with Costa and Kallick's (2014) call for all schools to implement some form of a dispositional framework, and are pleased with NYSED's (2018) adoption of three SEL goals. However, the authors do not support the explicit use of these goals or the CASEL (2018) competencies on which they are built as the authors find them to be vague and inaccessible to students, especially those at the middle level. The authors support the use of the dual objective (Vermette \& Kline, 2017) that enables teachers to set cognitive and affective goals for each lesson. The authors further propose that using the Habits of Mind (Costa \& Kallick, 2000) as they are mapped here to the CASEL (2018) five competencies best equips teachers to explicitly develop their students' $21^{\text {st }}$ century skills and their cognitive abilities.

\section{Declaration of Conflicting Interests}

The author declared no potential conflicts of interest with respect to the research, authorship, and/or publication of this article.

\section{Funding}

The authors received no financial support for this research. 


\section{References}

ACT (2019). ACT Tessera Reporting. Retrieved from: https://www.act.org/

Alhamlan, S., Aljasser, H., Amansour, H., \& Alahmad, N. (2018). A systematic review: Using Habits of Mind to improve students' thinking in class. Higher Education Studies, b, 1, 25-35. https://doi.org/10.5539/hes.v8n1p25

Borba, M. (2018). Nine competencies for teaching empathy. Educational Leadership, 76(2), 22-28.

Brackett, M.A., Rivers, S.E., Reyes, M.R. \& Salovey, P. (2012). Enhancing academic and social emotional competence with the RULER Feeling Words Curriculum, Learning and Individual Differences, 22(2), 213-224. https://doi.org/10.1016/i.lindif.2010.10.002

Brackett, M.A. (2018). The emotional intelligence we owe students and educators. Educational Leadership, 76(2), 12-18. https://doi.org/10.1016/j.lindif.2010.10.002

CASEL (Collaborative for Academic, Social, and Emotional Learning). (2018). Core SEL Competencies. Retrieved from: https://CASEL.org/core-competencies/

Costa, A. L., \& Kallick, B. (2000). Discovering \& exploring Habits of Mind. A Developmental series, book 1. Alexandria, VA: ASCD.

Costa, A. L., \& Kallick, B. (2014). Dispositions: Reframing teaching and learning. Thousand Oaks, CA: Corwin.

Covey, S. R. (1989). The seven Habits of highly effective people. New York: Simon \& Schuster.

DePaoli, J.L., Atwell, M.N., Bridgeland, J.M., \& Shriver, T.P. (2018). Respected: Perspectives of youth on high school social and emotional learning. A report for CASEL. Civic \& Hart Research Associates. Retrieved from https://casel.org/wp-content/uploads/2018/11/Respected.pdf

Duckworth, A. L., \& Yeager, D. S. (2015). Measurement matters: Assessing personal qualities other than cognitive ability for educational purposes. Educational Researcher, 44(4), 237-251. https://doi.org/10.3102/0013189X15584327

Duckworth, A. L. (2016). Grit: The power of passion and perseverance. New York: Scribner.

Durlak, J. A., Weissberg, R. P., Dymnicki, A. B., Taylor, R. D., \& Schellinger, K. B. (2011). The impact of enhancing students' social and emotional learning: A meta-analysis of school-based universal interventions. Child development, 82(1), 405-432. https://doi.org/10.1111/i.14678624.2010.01564.x

Dweck, C. S. (2008). Mindset: The new psychology of success. New York: Balantine Books.

Farrington, C.A., Roderick, M., Allensworth, E., Nagaoka, J., Keyes, T.S., Johnson, D., \& Beechum, N.O. (2012). Teaching adolescents to become learners. The role of non-cognitive factors in shaping school performance: A literature review. Chicago: UCCR on Chicago School Research.

Retrieved from https://www.greatschoolspartnership.org/wpcontent/uploads/2016/11/Teaching-Adolescents-to-Become-Learners.pdf

Fisher, D., \& Frey, N. (2013). Better learning through structured teaching: A framework for the gradual release of responsibility. Alexandria, VA: ASCD.

Glasser, W. (1999). Choice theory: A new psychology of personal freedom. New York: HarperPerennial.

Hattie, J. (2013). Visible learning for teachers: Maximizing impact on learning. London: Routledge. https://doi.org/10.4324/9780203181522

Hoerr, T. R. (2016). The Formative five: Fostering grit, empathy, and other success skills every student needs. Alexandria, VA: ASCD. 
Jagers, R.J., Harris, A., \& Skoog, A. (2015). A review of classroom-based SEL programs at middle school level, in J.A. Durlak, C.E. Domitrovich, R.P. Weissberg, R.P., and T.P. Gulotta (Eds.), Handbook of social emotional learning: Research and practice (pp. 167-180). New York: Guilford.

Leslie, I. (2014). Curious: The desire to know and why your future depends on it. New York: Basic Books.

National Academies of Sciences, Engineering, and Medicine. (2018). How people learn II: Learners, contexts, and cultures. National Academies Press. https://doi.org/10.17226/24783

New York State Education Department. (2018). New York State Social and Emotional Learning Benchmarks. Retrieved from: http://www.p12.nysed.gov/sss/documents/NYSSELBenchmarks.pdf

Pajares, F. (1996). Self-efficacy beliefs in academic settings. Review of Educational Research, 66(4), 543-578. https://doi.org/10.3102/00346543066004543

Ryan, R. M., \& Deci, E. L. (2000). Self-determination theory and the facilitation of intrinsic motivation, social development, and well-being. American Psychologist, 55(1), 68-78. https://doi.org/10.1037/0003-066X.55.1.68

Schwartz, D.L., Tsang, J.M., \& Blair, K.P. (2016). The ABC'of how we learn: 26 scientifically proven approaches, how they work, and when to use them. New York: W.W. Norton.

Steinberg, L. (2014). Age of Opportunity: Lessons from the new science of adolescence. Boston: Mariner.

Tough, P. (2016). Helping children succeed: What works and why. New York: Houghton Mifflin Harcourt.

Vermette, P.J., \& Kline, C. L. (2017). Group work that works: Student collaboration for $21^{\text {st }}$ century skills. New York: Routledge. https://doi.org/10.4324/9781315618364

Zachek, Emily. (n.d.). "Habits of Mind Posters". The Musical Middle. Teachers Pay Teachers. Retrieved from: https://www.teacherspayteachers.com/Product/Habits-of-Mind-Poster-Set-Neon-FullSheets-3281519 